\title{
RESEARCH PAPER \\ GLOBALIZATION OF THE FASHION INDUSTRY AND ITS EFFECTS ON GHANAIAN INDEPENDENT FASHION DESIGNERS
}

\author{
G. D. Sarpong, E. K. Howard, and K. Osei-Ntiri \\ Department of Industrial Art, Faculty of Art, College of Art and Social Sciences \\ Kwame Nkrumah University of Science and Technology \\ Kumasi, Ghana.
}

\begin{abstract}
:
This paper investigates the globalization of the fashion industry and its effects on Ghanaian independent fashion designers and finds feasible strategies that can be employed for the improvement of the fashion business in Ghana. The research is based on qualitative research approach which employs observation and interview for data collection. The population studied comprises fashion producers who have their workshops within twelve suburbs in Kumasi. The purposive sampling technique was utilized to select six respondents from each of the suburbs. Data collected was tabulated, interpreted and discussed. The study reveals among other things, that the Ghanaian fashion producers face serious challenges with the major one being importation of "seconds" and used clothes from Europe, America and cheap clothing and textiles from Asian countries. Lack of capital, knowledge and key skills, low and irregular income are among other challenges facing respondents. Strategies suggested for the improvement of the Ghanaian fashion business include; formation of strong alliance by all fashion producers in Ghana to influence the government to formulate policies that will address importation of fashion goods that compete unfairly with the Ghanaian fashion products, provide financial assistance in the form of loans to help in acquisition of current and more efficient machinery and raw material to improve and expand their businesses, and organise regular proficiency training for skills and competency upgrading to equip them to produce to meet international standards.
\end{abstract}

Keywords: Globalization; fashion; clothing; independent fashion designers; challenges

\section{INTRODUCTION}

The history of Ghanaian fashion is traced back to the pre-colonial era when indigenous Ghanaians used barks of trees and hides of animals to clothe themselves (Adu-Akwaboa, 1994). The development of fashion in Ghana is believed to have started during the colonial period with the introduction of wax prints and "dress" by the colonial masters (Turnings, 2002). Today, Gha- naian Fashion has undergone a complete overhaul because of globalization.

Fashion in its broadest sense is a particular style that is popular for a period of time. It can be clothing, furniture, housing, automobile, food, toys, and many others, but most commonly, it refers to a style of clothes, cosmetic, dress accessories, that is trendy, or most admi- 
rable and worn by many people at a particular time (Rouse, 1993; Drew 1992). Fashion as defined in a more technical manner comprises all sorts of clothing items, textiles fabrics and their study (Pearsall, 2002). It is clear from the above definitions that, fashion does not only refer to a style in vogue, but it is the term use for clothing and accessories for human body. It also includes textiles in the form of things made of fabrics for home, office and industrial furnishings as well as a programme of study. The Fashion Industry takes care of the production and sales of fashion products also. Fashion industry plays very prominent role in the socioeconomic development of every nation by helping generate income for living and it is a means through which people acquire their clothing needs.

Even though fashion change is intrinsic, today's fashion is being shaped by globalization. Jarnow and Dickerson (1997) assert that, globalization process is having tremendous impact on the fashion industry; the effect is that, where and how fashion is produced and marketed has changed. Jones (1998) describes globalization as a growing integration of the world's economy. To Walters (2002), it is a social process in which constraints of geography on economic, political, social and cultural arrangements recede and people become increasingly aware that they are receding. Hines and Bruce (2001) also assert that, globalization is the increasing internationalization of the production, distribution and marketing of goods and services, and the expansion of politics and cultures across the planet. It is apparent from these definitions that, the common phenomenon of the term globalisation is economic; thus the unit of economic activities and policies vis-a-vis political, social and cultural activities are expanding from nation to nation. Evidently, globalization is associated with technological advancement which facilitates the movement of people and goods worldwide. It can therefore be stated that globalization is the key means through which manufacturers produce and distribute their economic wealth in exchange for economic gains.
Dickerson (1999) comment that the fashion industry is not exempted from the globalization process, since the business of fashion is now a global economy. The striking effect is that, fashion designers, manufacturers, merchandisers and marketers are expanding their umbrellas throughout the whole world. Fashion manufacturing being labour intensive, has migrated from high wage developed world to developing countries; India, China, Indonesia, Bangladesh, and other Asian countries are generating valuable foreign exchange through exportation of clothing and textiles products to U.S.A., Europe and developing countries like Ghana and others (Jones, 1998; Bheda et al., 2003; Bird et al., 1996).

While developing countries like China, India and Hong Kong are earning valuable foreign exchange and building their wealth from exportation of Fashion products, Ghana's income generated from fashion production is very low. Attempts have been made by Ghana's consecutive governments of the fourth republic to develop and improve the industrial sector of the country. Fashion education has also been improved; it is now being studied at the tertiary level of Ghana's educational institutions, where graduates are expected to acquire quality demand-driven employable and marketable skills that will make them take their roles in the industrial sector, work and be economically productive (Amankwah, 2007). Yet the fashion businesses in Ghana are still dominated by ubiquitous roadside dressmakers whose market value is very low. Their main production is based on "custom-made" items. The main Ghanaian fashion export destinations comprising of EU countries, U.S.A. and some parts of the ECOWAS have declined due to competition with other African countries and poor finishing of products which make products not able to conform to standards required (Quartey, 2006).

There is also an assumption that, producers face big competition from imports of surplus clothing rejected by the thrift shops of Europe and America, and cheaper clothes and textiles from 
Asia especially China and Indonesia. All these have resulted from global economic expansion of the textiles and clothing industry. The aim of this study, therefore, is to investigate the problems that the independent fashion designers face amidst globalization of the fashion industry, and suggest feasible strategies for the improvement of their businesses.

\section{METHODOLOGY}

Empirical evidence shows that the validity and reliability of easy information for a study depends to a great extent on the strategies designed and used for the collection of data (Cooper, 1985). For this reason, qualitative research method which allowed close interactions with the respondents and their settings was employed for the study. The strategy included both formal and informal interviews and observations. This assisted the researchers to obtain first-hand information of the opinions, attitudes and behaviours of the designers (Osuala, 2001).

\section{Population/Sample Technique}

The accessible population for the study comprises independent fashion designers who have their settings at Adum, Amakom, Asafo, Asawase, Asokwa, Bantema, Krofrom, Oforikrom, Old Tafo, Santase, Kwadaso and Suame. These were chosen as fair representation of the population for the study in the Kumasi metropolis, as most of the independent fashion designers are clustered in these areas. Purposive sample technique was employed to sample out seventy two (72) respondents, that is, six independent fashion designers were chosen from each of the suburbs listed above. The use of purposive sampling technique helped in the selection of respondents who provided relevant and factual information for discussion (Leedy and Ormrod, 2005). The respondents selected mainly employ apprentices in their production processes. Few of them employ "work and pay" personnel who are Intermediate fashion graduates from the country's Polytechnics and Technical/ Vocational Institutions.

\section{Instruments for Data Collection}

The instruments used for data collection were participant observation and formal interview. The interview guide and observational checklist were developed based upon the following objectives:

- To find out the qualification of the respondents

- To identify the type of products they produce

- To examine the challenges facing the respondents

- To suggest strategies that are feasible for the improvement of the independent fashion designers

During the administration of the questionnaire, respondents were assured of anonymity and confidentiality which made them responded positively.

\section{RESULTS AND DISCUSSION}

The results of the study have been tabulated and discussed descriptively.

Table 1: The qualification of respondents

\begin{tabular}{llll}
\hline Qualification & Freq. & Percentage (\%) & Cum. Freq. (\%) \\
\hline HND Fashion and Textiles Studies & 5 & 7 & 7 \\
Advanced Fashion & 16 & 22 & 29 \\
Intermediate Fashion & 8 & 11 & 40 \\
Apprenticeship (certificate in Dressmaking) & 43 & 60 & 100 \\
Total & 72 & 100 & \\
\hline
\end{tabular}

Source: Field Study-2009 


\section{Sarpong et al.}

As indicated in Table 1, five (5) out of the seventy two (72) respondents representing $7 \%$ hold the highest qualification in Fashion Design and Textiles Studies, sixteen (16) of them representing 22\% have Advanced Fashion Certificates, eight (8) representing $11 \%$ posses Intermediate Certificate in Fashion, and forty three (43) representing 60\% went through apprenticeship to acquire training certificate in Dressmaking.

It is noticed that, those with the highest certificates constitute the least number in the fashion business with the majority of the respondents having the lowest qualification. It is evident that, the graduates who have been trained to acquire in-depth skills from the country's tertiary institutions do not find setting up their own business with the knowledge and skills acquired attractive. It must be argued that, the quality of fashion items that are produced will not be of good quality as majority of fashion designers within the study area use their apprentices (those that are still receiving training) for the production processes. This confirms the assertion made by Zwane et al. (2002) that the use of unskilled labour compromises the quality standards in production of garments. The reason is that these apprentices lack the requisite knowledge and key skills to come out with good garment construction details and specifi- cations like even seam widths, neat edge finishes and neatening techniques, effective use of elements and principles of design and others which the tertiary fashion institutions offer to improve the aesthetic quality and durability of fashion products, hence the rejection of most of the exports of the locally made fashion goods by EU and USA.

From Table 2, it is apparent that, Forty (40) out of the seventy two (72) respondents representing $55.6 \%$ acquire their capital and other financial resources from their own accumulated savings (Susu). Ten (10) being 13.8\% receive financial support from their own accumulated savings (Susu) and support from their families. Another ten (10) representing $13.8 \%$ receive financial support from their own accumulated savings (Susu) as well as loans from financial institutions, while the remaining twelve (12) representing $16.7 \%$ solicit financial assistance from all the three sources. This clearly shows that the fashion designers in the area depend mainly on their own savings to remain in business.

From Table 2, it is apparent that, Forty (40) out of the seventy two (72) respondents representing 55.6\% acquire their capital and other financial resources from their own accumulated savings.

Table 2: Sources of financing

\begin{tabular}{llll}
\hline Sources of Financing & Freq. & Percentage (\%) & Cum. Freq. (\%) \\
\hline Own accumulated savings (Susu) only & 40 & 55.5 & 55.5 \\
$\begin{array}{l}\text { Own accumulated savings (Susu) and } \\
\text { Families' financial support }\end{array}$ & 10 & 13.9 & 69.4 \\
$\begin{array}{l}\text { Own accumulated savings (Susu) and } \\
\text { Loans from financial institutions }\end{array}$ & 10 & 13.9 & 83.3 \\
$\begin{array}{l}\text { Own accumulated savings (Susu), } \\
\text { Families' financial support and Loans } \\
\text { from financial institutions }\end{array}$ & 12 & 16.7 & 100.0 \\
Total & 72 & 100 & \\
\hline
\end{tabular}

Source: Field Study-2009 
Table 3: Types of equipment used

\begin{tabular}{llll}
\hline Equipment & Freq. & Percentage (\%) & Cum. Freq. (\%) \\
\hline Industrial sewing machine only & 2 & 3 & 3 \\
$\begin{array}{l}\text { Industrial and domestic electric } \\
\text { machines }\end{array}$ & 4 & 5 & 8 \\
$\begin{array}{l}\text { Domestic electric machines and } \\
\text { hand sewing machines }\end{array}$ & 20 & 28 & 36 \\
$\begin{array}{l}\text { Domestic hand sewing machines } \\
\text { only }\end{array}$ & 46 & 64 & 100 \\
Total & 72 & 100 & \\
\hline
\end{tabular}

Source: Field Study-2009

Table 4: Type of textiles and fashion produced by the independent fashion designers

\begin{tabular}{llll}
\hline Product & Freq. & Percentage (\%) & Cum. Freq. (\%) \\
\hline $\begin{array}{l}\text { Textile fabrics- batik, tie and dye, } \\
\text { screen printing }\end{array}$ & 2 & 3 & 3 \\
$\begin{array}{l}\text { Textile fabrics- batik, tie and dye, } \\
\text { prints and garment }\end{array}$ & 10 & 14 & 17 \\
$\begin{array}{l}\text { Garments only (mainly custom- } \\
\text { made ones) }\end{array}$ & 60 & 83 & 100 \\
Total & 72 & 100 & \\
\hline
\end{tabular}

Source: Field Study-2009

Table 5: Multiple responses on challenges facing respondents

\begin{tabular}{lll}
\hline Challenges & Freq. & Percentage (\%) \\
\hline $\begin{array}{l}\text { Lack of Capital and Credit Facilities to acquire current } \\
\text { and more efficient equipment, tools and materials }\end{array}$ & 100 \\
Low and Irregular Income & 41 & 57 \\
High income tax, high utility bills and rent. & 60 & 69 \\
Lack of market & 50 & 75 \\
Competition of cheap imported clothes & 61 & 85 \\
Lack of knowledge and skills in the use of clothing & 64 & 86 \\
construction techniques for sewing, and skill to create & & \\
and make personal innovations & & \\
\hline Source: Field Study-2009 &
\end{tabular}




\section{Sarpong et al.}

Ten (10) being $13.8 \%$ receive financial support from their own accumulated savings (Susu) and support from their families. Another ten (10) representing $13.8 \%$ receive financial support from their own accumulated savings (Susu) as well as loans from financial institutions, while the remaining twelve (12) representing $16.7 \%$ solicit financial assistance from all the three sources. This clearly shows that the fashion designers in the area depend mainly on their own savings to remain in business.

The results presented in Table 3 indicate that, two (2) of the respondents representing 3\% use industrial sewing machines only for production. Four (4) of the respondents, that is 5\% use industrial as well as domestic electric machines for sewing, twenty (20) of them representing $28 \%$ use domestic electric and hand sewing machines whiles forty-six (46) representing $64 \%$ making use of hand sewing machines only for production. This reveals that there is very low usage of industrial sewing machines by the independent fashion designers in the study area.

As shown in Table 4, two (2) respondents representing $3 \%$ are into the production of only textile fabrics comprising batik, tie and dye, and screen printed fabrics. Ten (10) participants representing $14 \%$ produce batik, tie and dye, screen printed fabrics, and sew garments for customers. Sixty (60) respondents, that is, $83 \%$ sew garments which are mainly custom-made. In addition, the study reveals that, respondents use assorted textile fabrics. Cotton fabrics of various types including woodin, wax prints, java, fancy, tie-dye, batik and locally screen printed fabrics are dominant. Other fabrics like satin and nylon are also used, but mainly for dresses which are ordered by their local customers during occasions like Christmas, Easter and other festivities.

Results presented in Table 5 show that each of the respondents faces two or more challenges. Apparently, the most serious problem facing the respondents is lack of capital to improve their businesses. All the seventy two (72) re- spondents lack capital and credit facilities to acquire modern and more efficient equipment, tools and materials to work effectively. Forty one respondents (41) representing 57\% have low and irregular income. The income rate depends on the number of fabrics that the customers bring to sew and this is not predictable as customers usually bring more fabrics to be sewn for them during occasions and festival periods. Fifty respondents (50), that is, $69 \%$ expressed concern about high income tax imposed on them, coupled with high utility bills and rent. Fifty four (54) being $75 \%$ of the respondents complain that they do not have market for their products. It is noted that, these respondents apart from serving the clothing needs of their customers sew some few clothes for sale. However, these clothes usually receive low patronage in the sense that customers most often pay less than the production cost.

Table 6 also indicated that sixty one (61) respondents representing $85 \%$ are faced with competition of imported clothes sold in shops near their premises and second hand clothes that porters carry from door to door which are cheaper compared to the custom made clothes made by the independent fashion designers.

This gives a true indication of the assumption that imports of used and cheaper clothes and textiles onto the Ghanaian markets pose a big threat to the success of the Ghanaian fashion businesses. The findings of the study from Table 5 also indicate that sixty four (64) being $86 \%$ of the respondents lack knowledge and skills in the use of clothing construction techniques for sewing, and they find it difficult to create and make their own styles and for that matter depend solely on fashion catalogues and already made designs from fashion magazines and calendars to cut out their patterns. This hinders creativity and innovation in the local fashion business which makes them less competitive to the imported clothes.

Seventy one (71) respondents which represent $99 \%$, as indicated in Table 6, suggested the 
need for financial support and credit facilities to enable them acquire the current and efficient sewing tools, equipment and materials to expand their businesses. Sixty nine (69) that is $95 \%$ were of the view that, organisation of periodic skills and competency based workshops would be of great assistance towards the improvement and upgrading of their work. In addition, sixty five (65) of the respondents representing $90 \%$ agitated for the ban of the importation of fashion goods into the country, whereas forty three (43) being 59\%, proposed for the organisation of regular fashion fairs, shows and exhibitions at cheaper cost to enable them participate fully to showcase, sell and advertise their products.

The findings presented in the tables evidently show that, although the respondents face serious financial constraints, they are also much vulnerable in terms of skills and competencies in textiles and garment production. Inadequate capital for the acquisition of efficient tools, equipment and materials to support respondents go through training to upgrade their skills and competencies are the key problems facing them. Majority of the respondents operate their businesses with their own savings through 'Susu' with very few of them receiving some financial support from their families. Few of the interviewees have access to loans from financial institutions. Evidently, domestic sewing machines are the common equipment being used by the respondents. This is not a good scenario in the face of the local fashion industry which aims at producing to meet international standards in terms of design and construction of high quality and well finished fashion products in order to compete fairly with the offshore counterparts.

It can be deduced therefore that, financial challenges and lack of relevant knowledge, key skills and competencies for the production of variant and internationally marketable fashion products are prevalent in the Ghanaian fashion industry. The researchers are sure of commenting on this since similar findings about this have resulted from other studies (Adamptey 2007; Sarpong, 2005). While some developing nations are enjoying positively from the interconnected global economy of the textiles and apparel businesses, the case of Ghana is different. Studies have shown that, USA and some developed European countries have most of their fashion firms in Asia where their garments are manufactured and exported within the shortest possible time, using CAD and CAM technology as well as electrically transformed gadgets and facilities. This has made Asian countries, especially China, India and Bangladesh; generate valuable foreign exchange through fashion business (Jones, 1998; Dickerson 1999). A clear evidence of this is the bombardment of the Ghanaian fashion market with cheap and imitated fashion goods from Asia (Sarpong 2005; Quartey, 2010). This interconnected global economy has facilitated the

Table 6: Multiple responses on suggestions for improvement of their businesses

\begin{tabular}{lll}
\hline Suggestions & Freq. & Percentage (\%) \\
\hline Financial Support in the form of loans and credit facilities & 71 & 99 \\
$\begin{array}{l}\text { Formal training for improving and upgrading skills and } \\
\text { competency based workshops }\end{array}$ & 69 & 95 \\
Barn of importation of fashion goods into the country & 65 & 90 \\
$\begin{array}{l}\text { Regular organization of Fashion Trade Fairs, shows and } \\
\text { Exhibition at cheaper cost to enable participation of } \\
\text { Dressmakers }\end{array}$ & 43 & 59 \\
\hline
\end{tabular}

Source: Field Study-2009 


\section{Sarpong et al.}

importation of "seconds" and used clothing from the Western world. All these have become global challenges to the independent fashion producers in Ghana.

As indicated in the introductory section of this paper, Ghana governments of the fourth republic have made several attempts to develop and improve the Garment and Textiles industry, but not all attempts have yielded positive results. The Ghana government in collaboration with the United Nations Industrial Development Organisation (UNIDO) in 2003 established garment and textiles manufacturing training programme at Accra Technical Training Centre for hands-on-training and skill upgrading in garment manufacturing for individuals in the fashion industry (Sarpong, 2005). For instance, former President Kufuor, under the President Special Initiative (PSI) on Garment and Textiles production began negotiations with major textiles and garment manufacturing countries to invest in the country in order to get as many individuals to be employed and learn on the job experience (Turlings, 2002). Despite these and other efforts by Ghana government toward development and improvement of the local fashion business, the industry still struggles to survive due to a number of challenges it is confronted with as revealed in this study. A critical look of the suggestions made by respondents in the study is therefore crucial to help revamp their fashion businesses.

One of the most important aspects that form the backbone of every industry is capital as it is the means through which all the resources to generate wealth are acquired. The study therefore stresses the need for the government and other stake holders to realize the importance of making loans and credit facilities available to the independent fashion producers who operate in the small-scale sector, to enable them acquire current and efficient tools, equipment and other gadgets to help improve their skills and proficiency, the quality of their products, and expand their businesses. Furthermore, it should be noted that, popular Fashion Designers like
Vivienne Westwood, Giorgio Armani, Paul Smith, Dolce and Gabbana, Christine Dior, Chloe, and others evolve new patterns and classic fashions through training and practice (Rouse, 1999). It is therefore recommended that, Ghanaian fashion designers should take vocational training and practice as key elements to perfect performance and productivity. Those who are in the business should find it necessary to acquire training that will assist them to improve their skills. This can be done by organizing themselves into groups and inviting experts from the tertiary institutions and experience fashion designers to assist them upgrade their skills and competencies in product quality development and innovations that will make them experts in their field in order to gain international market recognition.

With regard to the competition posed by the importation of new and used clothing and textiles, a collective approach is required to address the issue. In support to the opinions expressed by Boakye (2010) and Adamptey (2009), the study calls for all fashion producers especially small-scale manufacturers in Ghana to form strong alliance in order to stand and gather effective force to put their grievances forward to parliament and other stake-holders who formulate and implement policies to address importation of fashion goods that compete unfairly with the Ghanaian products. For example, only textile fabrics that are not easily produced and are needed in the country should be imported to save the local textiles and clothing industry from collapsing. This means that, some restriction on importation of textile products should be enforced.

To manage the competition, the research team contend that superior marketing strategies should be adopted. These should include a complete market research to be made by the educated producers to acquire information about sizes and structures of the fashion market, current trends, consumers' preferences, competitors, advertising effectiveness, pricing and information on how to penetrate through 
the fashion market successfully (Easey, 2002). The researchers opine that, successful employment is created when the economic climate is favourable, therefore the government of Ghana should take the acceleration of the growth of the fashion industry more seriously, especially, by initiating supports that will make the fashion industry more attractive and viable, assist in investment and penetration of the international market.

\section{CONCLUSION}

In the $21^{\text {st }}$ century of global challenges in all hemisphere of life, the innovations and dynamism in the fashion industry cannot be over emphasized. A great competition is therefore set among fashion industries in the developed and the under developed world causing most vulnerable local industries to collapse. The fashion industry of Ghana is not exempted in this regard with the independent fashion designers being the most affected. Their businesses have been crippled by the influx of foreign clothes and textiles on the Ghanaian market on the ticket of Trade Liberalization in the global front. It is an arguably fact that the liberal trade in the global world has had a negative impact on the local fashion industries. In order to sustain the businesses of the local designers, the local industrialists have the hope that the ban of unnecessary importation of foreign clothes and textiles, especially the second-hand types, can go a long way to revive the clothing and textiles sub-sector. This, to the research team, is arguably not realistic as Ghana is a member of WTO whose policies encourage liberal trade and frown on protectionism. What Ghana ought to do is to device means of improving the skill and competency base of its fashion producers to make them efficient, experts, and result oriented, and to be abreast with modern technology in fashion. Whiles doing this, the government must equip and develop the sub-sector to be viable by resourcing the independent fashion producers financially to enable them acquire modern and efficient fashion machinery so as to produce quality garments to meet international standards.

\section{REFERENCES}

Adamptey, S. K. (2009). Vocational/Technical Education in Ghana: Problems and Remedies. International Journal of Home Economics Research. 1 (1): 189-191.

Amankwah, A. A. (2007). Public Agenda. Retrieved 26/09/2007 from www.ghanaweb.com.

Boakye, K. (2010). Challenges Facing the Small Scale Textile and Garment Industry in Ghana (Unpublished).

Bheda, R., Narag, A. S. and Singla, M. L. (2003). Apparel Manufacturing: A Strategy for Productivity Improvement. Journal of Fashion Marketing and Management. 7 (1): 12-22

Cooper, H. M. (1985). The Integrative Research Review: A Systematic Approach; Sage Ltd., London.

Dickerson, K. G. (1999). Textiles and Apparel Business in the Global Economy. Prentice Hall, U.S.A.

Drew, L. (1992). The Business of Fashion, Cambridge University Press, UK.

Easey, M. (2002). Fashion Marketing. (Second Edition), Blackwell, UK.

Hines, T. and Bruce, M. (2001). Fashion Marketing (Contemporary issues), Butterworth Heinemann, U.S.A.

Jarnow, J. and Dickerson, K. G. (1997). Inside the Fashion Business, ( $6^{\text {th }}$ Edition), Prentice Hall., U.S.A.

Jones, L. (1998). Fashion Victims, Together We Can Clean Up The clothes Trade, CAFOD, UK.

Jones, S. J. (2002). Fashion Design, Laurence King Publishing, UK. 
106 Sarpong et al.

Leedy, P. D. and Ormrod, J. E. (2005). Practical Research: Planning and Design. $\left(8^{\text {th }}\right.$ Edited). Pearson Education Inc. New York.

Mike, E. (2002), Fashion Marketing (Second Edition), Blackwell Science Ltd. UK.

Motkya, E. M, (1989). Step-by-step Sewing Book, McCall's Ltd. U.S.A

Osuala, E. C. (2001) Research Methodology. Revised edition, Enugu: Fulladu Publishers.

Pearsall, J. (2002). Concise Oxford English Dictionary, Oxford University Press, New York.

Quartey, P. (2007). Textiles and Clothing In- dustry in Ghana, (Library.fes.de/pdf-files/ iez/03796/10ghana.pdf).

Rouse, E. (1999). Understanding Fashion, MPG Books Ltd, UK.

Sarpong, G. D. (2005). Challenges of the Fashion Industry to Polytechnic graduate (Unpublished Dissertation).

Turlings, Y. (2002). Ghana Investment Profile, Retrieved 14/09/2003 from www.ghana.textilenews.org.

Zwane, P., Richarda, L. And Edmond, M. (2002). Apparel Production in Swaziland: The Need for Industry Educa- tion. Journal for Clothing and Textile Research, 20 (4): $256-281$. 